\title{
External Macroeconomic Factors and the Link between Short- and Long-Run European Interest Rates: A Note
}

\author{
Mariam Camarero, ${ }^{*}$ Javier Ordóñez, $†$ and Cecilio Tamaritł
}

\begin{abstract}
This article analyzes the long-run relationships linking long- and short-run interest rates for the Euro-wide aggregated variables. To this end, we extend the set of variables traditionally involved in the Campbell and Shiller (1987) framework for the term structure to add external macro variables (the exchange rate, U.S. inflation, and U.S. short-run interest rates). Our results support the expectations hypothesis and also stress the importance of accounting for foreign economy influences on European monetary policy, namely, the real exchange rate of the American dollar as well as real interest rates.
\end{abstract}

JEL Classification: C32, E43, E52

\section{Introduction}

The most recent literature on the term structure of interest rates suggests that the seminal model of Campbell and Shiller (1987), consisting of the spread and the change in the short-term rate in a vector autoregressive (VAR) specification, could be too parsimonious to fit the data (Carriero, Favero, and Kaminska 2006). In fact, this bivariate approach includes an implicit reaction function, where the only determinants of policy rates are long-term rates. Therefore, there are potential misspecifications due to the omission of macroeconomic factors. To solve this problem, some authors have considered the inclusion of other macroeconomic variables, "à la Taylor," to which monetary policymakers react. The usual potential onitted variables involved in the augmented models are internal ones, namely, inflation, output, or employment movements. However, the external determinants have been only scarcely studied. ${ }^{1}$

* Department of Economics, Jaume I University, Avda. Sos Baynat, s/n, 12530, Castelón, Spain; E-mail camarero@eco.uji.es; corresponding author.

† Department of Economics, Jaume I University, Avda. Sos Baynat, s/n, 12530, Castellón, Spain; E-mail jmonfort@eco.uji.es.

‡ Department of Applied Economics II, University of Valencia, Valencia, P.O. Box 22 006, Spain; E-mail cecilio.tamarit@uv.es.

The authors gratefully acknowledge the financial support from the CICYT Project SEJ2C05-001163 (Spanish Ministry of Education and FEDER), Generalitat Valenciana Complementary Action ACOMPLE07/102, and the Bancaja research project P1.1B2005-03. The authors are members of the Research Group "Inteco." We thank two anonymous referees for helpful comments. The usual disclaimer applies.

Received October 2007; accepted March 2008.

' This kind of extension has already been addressed from an empirical point of view in Bekaert and Hodrick (2001), who use a VAR containing long- and short-run interest rates and the exchange rate to test jointly for the expectations hypothesis of the term structure and the uncovered interest rate parity. 
In this article, we propose the inclusion of a new set of variables ("à la McCallum") compatible with the endogenous policy reaction model developed by McCallum (2005). Assuming that policymakers adjust interest rates in order to keep exchange rates stable and that they are interested in smoothing interest rate movements, McCallum develops a reduced-form equation for the spot exchange rate under rational expectations. From McCallum (2005), if the European Central Bank (ECB) smoothes the path for short-run interest rates, and if it weighs in the exchange rates when formulating policy, then simple tests of the expectations hypothesis $(\mathrm{EH})$ could be severely biased. Therefore, by taking into account the external influences of foreign economy, the fit of the EH may be improved. In other words, expectations of the short rate may explain a greater share of long-run rate variability than simple tests may indicate. Kluger (2000) generalizes this result by taking into account the policy reaction to the term spread in addition to the exchange rate. According to this model, the central bank increases the short-run rate in response to a depreciating exchange rate or a widening spread, which signals higher expected future inflation.

According to Neely (2001), there are at least three reasons central banks might tend to change their interest rate targets in a similar fashion. First, countries react similarly to common shocks. Central banks take into account the state of the economy, including international conditions, such as commodity prices (i.e., oil), to implement monetary policy. Therefore, if changes in such prices tend to affect countries in the same way, they lead to similar monetary policy measures. Second, in an integrated economy, countries may desire to maintain stable exchange rates, and, consequently, central banks might minimize swings in the external value of their currencies, leading to coordinated policy measures. Third, economic conditions in one country affect those in other countries through trade and capital flows. A U.S. recession that leads to lower U.S. interest rates might also slow down its trading partners' growth, prompting their central banks to lower rates as well.

It has been claimed that with the formation of the European Monetary Union (EMU), monetary policy in Europe may be more concerned with European trends and less concerned with external factors than the central banks of the constituent states used to be. Although this statement can be true and monetary policy is not, certainly, a game of "follow the leader," all in all we think that the ECB considers the effect of external factors, including foreign interest rates, when making monetary policy for its own countries (Belke and Gross 2005; Brüggemann and Lütkepohl 2005).

Therefore, in this article, we contribute to previous empirical literature by augmenting the original VAR framework proposed by Campbell and Shiller (1987) with additional variables. Specifically, to control for worldwide effects on Euro-area interest rates, the variables we consider are the U.S. short-run interest rates, U.S. inflation, and the euro/dollar exchange rate. Once foreign interest rates and the exchange rate are included in the VAR, not only the $\mathrm{EH}$ of the term structure but also the $\mathrm{EH}$ in the foreign exchange market plays a role.

According to our results, the inflation rate decreases not only because of the evolution of the short-run interest rates controlled by the ECB but also as a joint consequence of a higher degree of international competitiveness (and economic integration). Thus, long-run interest rates react to exchange rates, and this reaction might be precisely because of the anticipated future reactions of the ECB to the exchange rates. In turn, this interpretation supports the EH. 


\section{Empirical Results}

We analyze the following quarterly data:

$$
x_{t}^{\prime}=\left[l_{t}, i_{t}, q_{t}, \Delta p_{t}, i_{t}^{*}, \Delta p_{t}^{*}\right] \quad t=1986: 1 \text { to } 2005: 2,
$$

where $l_{t}, i_{t}$, and $p_{t}$ are, respectively, the aggregated long- and short-run interest rates and the price index (in logs) for the Euro area obtained from the area-wide database by Fagan, Henry, and Mestre $(2005){ }^{2} q_{t}$ is the log of the real euro/dollar exchange rate, expressed as units of euro per dollar; and $i_{t}{ }^{*}$ and $p_{t}{ }^{*}$ are, respectively, the U.S. short-run interest rate and the price index (in logs). All data have been taken from the International Financial Statistics database. The interest rates have been divided by 400 to make the estimated coefficients comparable with logarithmic quarterly changes.

The empirical analysis is based on the baseline VAR(2) model with the corstant restricted to the cointegration space:

$$
\Delta x_{t}=\Gamma \Delta x_{t-1}+\alpha \tilde{\beta}^{\prime} \tilde{x}_{t-1}+\Phi D p_{t}+\varepsilon_{t},
$$

where $\tilde{\beta}^{\prime}=\left[\beta^{\prime}, \beta_{0}, \delta\right]$ and $\tilde{x}_{t-1}=\left[x_{t-1}, D i_{t}\right]^{\prime}$. The parameter $\beta_{0}$ is the restricted constant. The coefficient $\delta$ stands for a mean shift in $\beta^{\prime} x_{t-1}$ as a result of mean shifts in the variables that do not cancel out in the cointegrated relations. These shifts are captured by the mean-shift dummy variables in $D i_{t}$. A mean shift in the variables implies a one-time dummy in first differences $D p_{t}$; therefore, the dummy takes the value of one for the period of the level shift.

From the analysis of the VAR residuals and in order to maintain the hypothesis of normality, three dummies were introduced and restricted to lie in the cointegration space, named $D i_{t}=\left[D s 881_{t}, D s 924_{t}, D s 991_{t}\right]^{\prime}$, where $D_{s} X X Y_{t}$ stands for a shift dummy that is equal to one from $19 X X: Y$ on and zero elsewhere. The shift dummy $D_{s} 881_{t}$ accounts for the NyborgBasilea agreement; whereas, $D_{s} 924_{t}$ and $D_{s} 991_{t}$ capture, respectively, the European Monetary System crisis in September 1992 and the beginning of the common monetary policy.

Previous to the cointegration analysis, we have tested for the stationarity of the variables using the Johansen procedure. The results are strongly in favor of rejecting the null hypothesis of stationarity for all the variables.

The misspecification tests suggest that the model is correctly specified. Additional tests on the individual variables and their role in the system allow us to conclude that none of the variables can be excluded from the cointegration space or be restricted as weakly exogenous.

The choice of the cointegration rank is made based on the Bartlett-corrected trace test, the roots of the characteristic polynomial, and the $t$-statistic of the adjustment coefficients. All this information is shown in Table 1. The cointegration rank is set to $r=3$.

Table 2 presents the identified structure of the cointegration relations. This overidentifying structure is accepted with a $p$-value of 0.43 . The first relation describes an interest rate rule,

\footnotetext{
${ }^{2}$ The use of pre-EMU data to infer future behavior of the ECB poses two major challenges. First. pre-EMU data are obtained by the aggregation of national data for a group of countries with, to some extent, different economic and institutional structures. Second, the creation of the EMU might cause a structural change in terms of monetary policy, and the estimated parameters could be subject to the Lucas (1967) critique. Despite these difficulties, the data used in this article have been found to be extremely useful in a number of practical contexts, such as forecasting and simulation (for reference, see Fagan, Henry, and Mestre 2005), showing that such data can be used to assess current effects of policy actions on the economy. In addition, we have accounted for possible structural changes using the tests available in the literature (in our case, the Hansen and Johansen [1999] test).
} 
Table 1. The Cointegration Rank ${ }^{\mathrm{a}}$

\begin{tabular}{|c|c|c|c|c|c|c|}
\hline \multicolumn{7}{|c|}{ Rank test for cointegration } \\
\hline p-r & $\mathrm{r}$ & Eigenvalue & Trace & Trace* & Frac95 & Simul95 \\
\hline 6 & 0 & 0.63 & 210.23 & 179.76 & 103.68 & 145.420 \\
\hline 5 & 1 & 0.45 & 133.88 & 114.83 & 76.81 & 107.61 \\
\hline 4 & 2 & 0.36 & 88.09 & 75.88 & 53.94 & 82.97 \\
\hline 3 & 3 & 0.36 & 53.94 & 47.64 & 35.07 & 59.84 \\
\hline 2 & 4 & 0.16 & 20.34 & 18.39 & 20.16 & 35.13 \\
\hline$\underline{1}$ & 5 & 0.09 & 7.07 & 6.54 & 9.14 & 20.20 \\
\hline \multicolumn{7}{|c|}{ Roots of the companion matrix (modulus) } \\
\hline Rank $=2$ & 1.00 & 1.00 & 1.00 & 1.00 & 0.66 & 0.57 \\
\hline Rank $=3$ & 1.00 & 1.00 & 1.00 & 0.66 & 0.63 & 0.62 \\
\hline \multicolumn{7}{|l|}{$\hat{\alpha}$ loadings } \\
\hline & $\Delta t_{t}$ & $\Delta i_{t}$ & $\Delta^{2} p_{t}$ & $\Delta q_{t}$ & $\Delta i_{t}^{*}$ & $\Delta^{2} p_{t}^{*}$ \\
\hline$\hat{\alpha}_{1}(t$-ratios $)$ & 3.18 & 4.40 & 5.10 & -1.21 & 0.09 & 8.08 \\
\hline$\hat{\alpha}_{2}(t$-ratios $)$ & -0.93 & -1.22 & -6.91 & 1.44 & -2.04 & -0.70 \\
\hline$\hat{\alpha}_{3}(t$-ratios $)$ & 1.29 & 3.85 & -0.07 & 3.03 & 1.60 & 2.50 \\
\hline
\end{tabular}

a The cointegration space is estimated following the Johansen procedure and using the program CATS by Dennis, Hansen, Johansen, and Juselius. Boldface indicates $t$-ratios $>2$. Trace* stands for the Bartlett corrections to the standard Trace test for the I(1) model. Frac95 are the critical values corresponding to a model without dummies. Simul95 are the simulated critical values at $5 \%$ for the $\mathrm{I}(1)$ model with shift dummies.

$$
i_{t}=i_{t}^{*}+\underset{[21.29]}{1.69}\left(\Delta p_{t}-\Delta p_{t}^{*}\right)+\underset{[10.95]}{0.01}-\underset{[-9.24]}{0.01} D s 924_{t},
$$

so that the ECB is expected to increase the short-run interest rates either when the U.S. short-run interest rate increases or when European inflation is higher than in the United States. The shift in the equilibrium mean estimated by the dummy $D_{s} 924_{t}$ suggests that the level of short-run interest rates decreases by 0.01 in the period after the Exchange Rate Mechanism (ERM) crisis.

The second cointegration vector corresponds to a relationship linking the European shortrun real interest rates with the foreign short-run interest rates and the real exchange rate, ${ }^{3}$

$$
\left(i_{t}-\Delta p_{t}\right)=\underset{[29.35]}{1.61}\left(i_{t}^{*}-\Delta p_{t}^{*}\right)+\underset{[5.63]}{3.03} q_{t}+\underset{[10.62]}{0.03} D s 924_{t}-\underset{[-10.55]}{0.03} D s 991_{t},
$$

and might capture the degree of financial integration between the two areas. The ERM crisis caused an increase in the European short-run real interest rates; whereas, the adoption of a common monetary policy in Europe caused a decrease.

Finally, the third cointegration relation can be arranged to describe a link between shortrun interest rates and the spread between short and long-run interest rates in Europe,

$$
i_{t}=\underset{[17.33]}{1.20}\left(l_{t}-i_{t}\right)-\underset{[19.42]}{0.012}+\underset{[6.65]}{0.012} D s 991_{t},
$$

where the estimated parameter 1.20 is the reaction coefficient of monetary policy to the spread.

\footnotetext{
${ }^{3}$ The implication is that the purchasing power parity condition is likely to be strongly related to the uncovered interest rate parity. There is a large empirical literature that points to the adequacy of testing both parities jointly (Johansen and Juselius 1992; Juselius 1995; Camarero and Tamarit 1996; Juselius and MacDonald 2004).
} 
Table 2. The Restricted Model ${ }^{\mathrm{a}}$

\begin{tabular}{|c|c|c|c|c|c|c|c|c|c|}
\hline \\
\hline \multicolumn{10}{|c|}{$\begin{array}{cc}\text { Long-run relationships } \\
l_{t} & i_{t}\end{array}$} \\
\hline \multirow[t]{2}{*}{$\tilde{\beta}_{1} \quad-$} & $\begin{array}{l}1.00 \\
{\left[\begin{array}{ll}N & A\end{array}\right]}\end{array}$ & -1.69 & - & -1.00 & $\begin{array}{l}16.9 \\
{[21.29]}\end{array}$ & - & $\begin{array}{l}0.01 \\
9.24]\end{array}$ & - & \multirow{2}{*}[-10.95]{} \\
\hline & $\begin{array}{l}1.00 \\
{\left[\begin{array}{ll}N & A\end{array}\right]}\end{array}$ & -1.00 & $\frac{-3.03}{[-5.63]}$ & $\begin{array}{l}-1.61 \\
{[-29.35]}\end{array}$ & $\begin{array}{l}1.61 \\
{[29.35]}\end{array}$ & - & $\begin{array}{r}-0.03 \\
{[-10.62]}\end{array}$ & $\begin{array}{l}0.03 \\
{[10.55]}\end{array}$ & \\
\hline $\begin{array}{l}1.00 \\
{\left[\begin{array}{l}N \\
A\end{array}\right]}\end{array}$ & $\begin{array}{l}-1.83 \\
{[-17.33]}\end{array}$ & - & - & - & - & - & - & $\begin{array}{r}-0.01 \\
{[-19.42]}\end{array}$ & $\begin{array}{l}0.01 \\
{[6.65]}\end{array}$ \\
\hline
\end{tabular}

Short-run structure

\begin{tabular}{|c|c|c|c|c|c|c|}
\hline \multicolumn{7}{|l|}{ Matrix $\Gamma$} \\
\hline & $\Delta l_{t}$ & $\Delta i_{t}$ & $\Delta^{2} p_{t}$ & $\Delta q_{1}$ & $\Delta^{2} p_{t}^{*}$ & $\Delta i_{t}^{*}$ \\
\hline$\Delta l_{t-1}$ & $\begin{array}{l}0.31 \\
{[2.40]}\end{array}$ & - & - & $\begin{array}{l}2.20 \\
{[10.78]}\end{array}$ & $\begin{array}{l}-1.35 \\
{[-2.51]}\end{array}$ & - \\
\hline$\Delta s_{t-1}$ & - & $\begin{array}{l}0.32 \\
{[3.38]}\end{array}$ & - & - & - & $\frac{-0.38}{[-3.22]}$ \\
\hline$\Delta^{2} p_{t-1}$ & - & - & -1.18 & $\begin{array}{l}3.69 \\
{[5.80]}\end{array}$ & - & \\
\hline$\Delta q_{t-1}$ & - & - & - & - & $\begin{array}{l}0.03 \\
{[2.85]}\end{array}$ & - \\
\hline$\Delta s_{t-1}^{*}$ & $\begin{array}{l}0.26 \\
{[2.22]}\end{array}$ & - & - & - & $\begin{array}{l}1.79 \\
{[3.38]}\end{array}$ & $\begin{array}{l}0.29 \\
{[2.65]}\end{array}$ \\
\hline$\Delta^{2} p_{t-1}^{*}$ & - & - & $\begin{array}{l}0.24 \\
{[2.32]}\end{array}$ & - & $\begin{array}{l}-0.85 \\
{[-6.68]}\end{array}$ & - \\
\hline
\end{tabular}

\begin{tabular}{|c|c|c|c|c|c|c|}
\hline \multicolumn{7}{|l|}{ Matrix $\alpha$} \\
\hline$e c m 1_{t-1}$ & - & $\begin{array}{l}-0.11 \\
{[-2.50]}\end{array}$ & $\begin{array}{l}1.12 \\
{[5.42]}\end{array}$ & $\underset{-3.95}{-11.01}$ & $\begin{array}{c}0.99 \\
3.72\end{array}$ & - \\
\hline ecm $2_{t-1}$ & $\frac{-0.03}{[-1.74]}$ & $\begin{array}{l}-0.19 \\
{[-4.04]}\end{array}$ & $\frac{-1.18}{[-5.19]}$ & $\begin{array}{l}9.61 \\
{[3.72]}\end{array}$ & $\begin{array}{l}-1.67 \\
{[-4.99]}\end{array}$ & - \\
\hline$e c m 3_{t-1}$ & - & - & $\begin{array}{l}-0.27 \\
{[-2.53]}\end{array}$ & - & $\begin{array}{l}-0.75 \\
{[-4.66]} \\
\end{array}$ & $\begin{array}{l}0.07 \\
{[2.54]}\end{array}$ \\
\hline \multicolumn{7}{|c|}{ Matrix $\Phi$} \\
\hline Dp881 & $\begin{array}{l}-0.01 \\
{[-2.37]}\end{array}$ & $\frac{-0.01}{[-3.40]}$ & - & - & $\begin{array}{l}-0.01 \\
{[-2.96]}\end{array}$ & $\frac{-0.01}{[-2.74]}$ \\
\hline Dp924, & - & -0.01 & - & $\frac{-0.12}{[-3.21]}$ & - & $\begin{array}{l}0.01 \\
{[2.21]}\end{array}$ \\
\hline Dp991 & - & - & - & - & - & - \\
\hline \multicolumn{7}{|c|}{ Misspecification tests } \\
\hline Nor. & \multicolumn{2}{|c|}{$\operatorname{AR}(1)$} & $\mathrm{AR}(4)$ & \multicolumn{2}{|c|}{ HTC } & $\mathrm{ARCH}$ \\
\hline 0.22 & \multicolumn{2}{|c|}{0.25} & 0.10 & \multicolumn{2}{|c|}{0.94} & 0.86 \\
\hline
\end{tabular}

${ }^{a}$ The long-run relationships are estimated following the Johansen procedure and using the program CATS by Dennis, Hansen, Johansen, and Juselius; whereas, the short-run structure has been estimated with PcFiml by Doornik and Hendry. ecm 1, ecm 2 , and ecm 3 stand, respectively, for the first $\left(\tilde{\beta}_{1}\right)$, second $\left(\tilde{\beta}_{2}\right)$, and thirc $\left(\tilde{\beta}_{3}\right)$ cointegration relationships; $t$-values in brackets. Nor denotes normality test. $A R(1)$ and $A R(4)$ denote, respectively, an LM test statistic for residual autocorrelation up to orders 1 and 4. HTC and $A R C H$ stand, respectively, for unconditional (White test) and conditional heteroscedasticity (Engle test). For Nor, $A R(1), A R(4), H T C$, and $A R C H$, only the $p$ values are reported. $D s 881_{t}, D s 924_{t}$, and $D s 991_{t}$ in the upper panel stand for the shift dummies restricted to lie in the

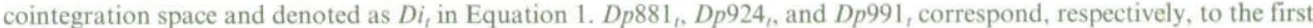
differences of $D s 881_{t}, D s 924_{t}$, and $D s 991_{t}$, formerly denoted as $D p_{t}$ in Equation 1.

Table 2 also presents a parsimonious representation of the short-run dynamic adjustment structure in which insignificant coefficients have been set to zero. The test of the 40 overidentifying zero restrictions was accepted based on $\chi^{2}(40)=66.00$ and a $p$-value of 0.87 . 


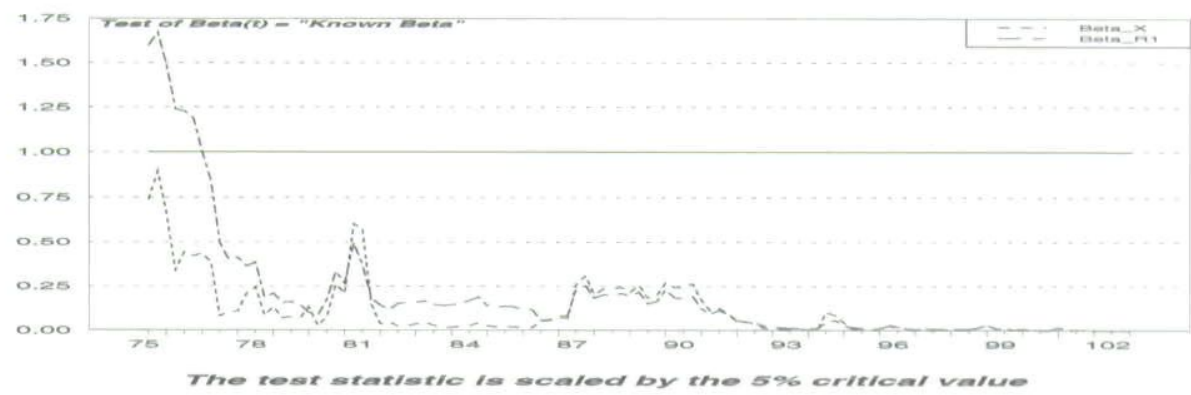

(a) Beta constancy
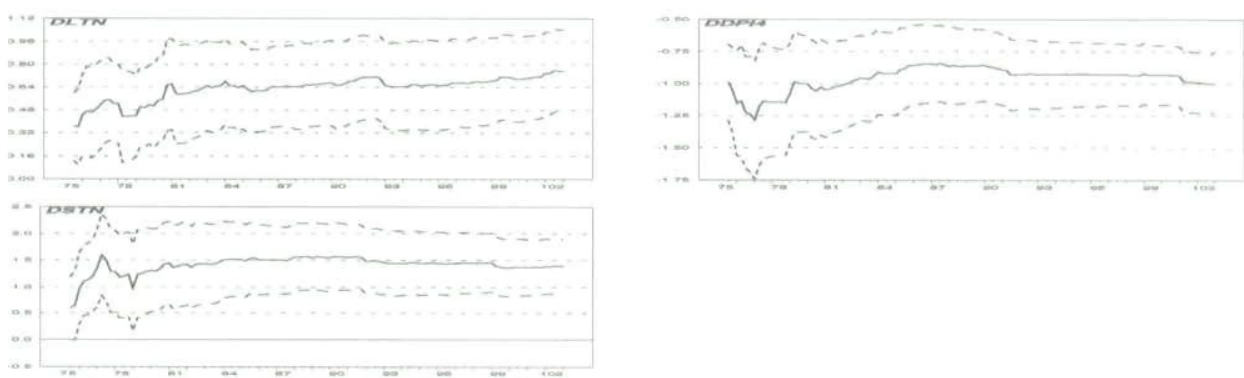

(b) $\hat{\alpha}_{1}$ constancy
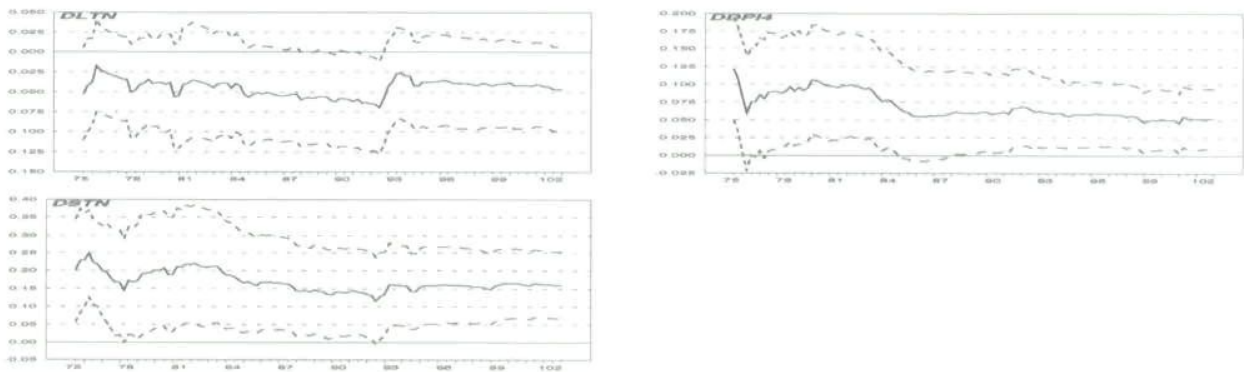

(c) $\hat{\alpha}_{2}$ constancy

Figure 1. Stability Tests: (a) $\beta$ Constancy, (b) $\hat{\alpha}_{1}$ Constancy, (c) $\hat{\alpha}_{2}$ Constancy

European short-run interest rates are equilibrium correcting to both the first and the second cointegration relationships. This implies that this variable is determined partly by the interest rate rule and partly by degree of financial integration.

European inflation rate is equilibrium correcting to the first cointegration relationship. Thus, an increase in the short-run interest rate would cause an inflation reduction. In addition, the negative adjustment coefficient to the second cointegration vector implies that inflation also decreases when the short-run real interest rate increases; the latter might cause a real exchange 

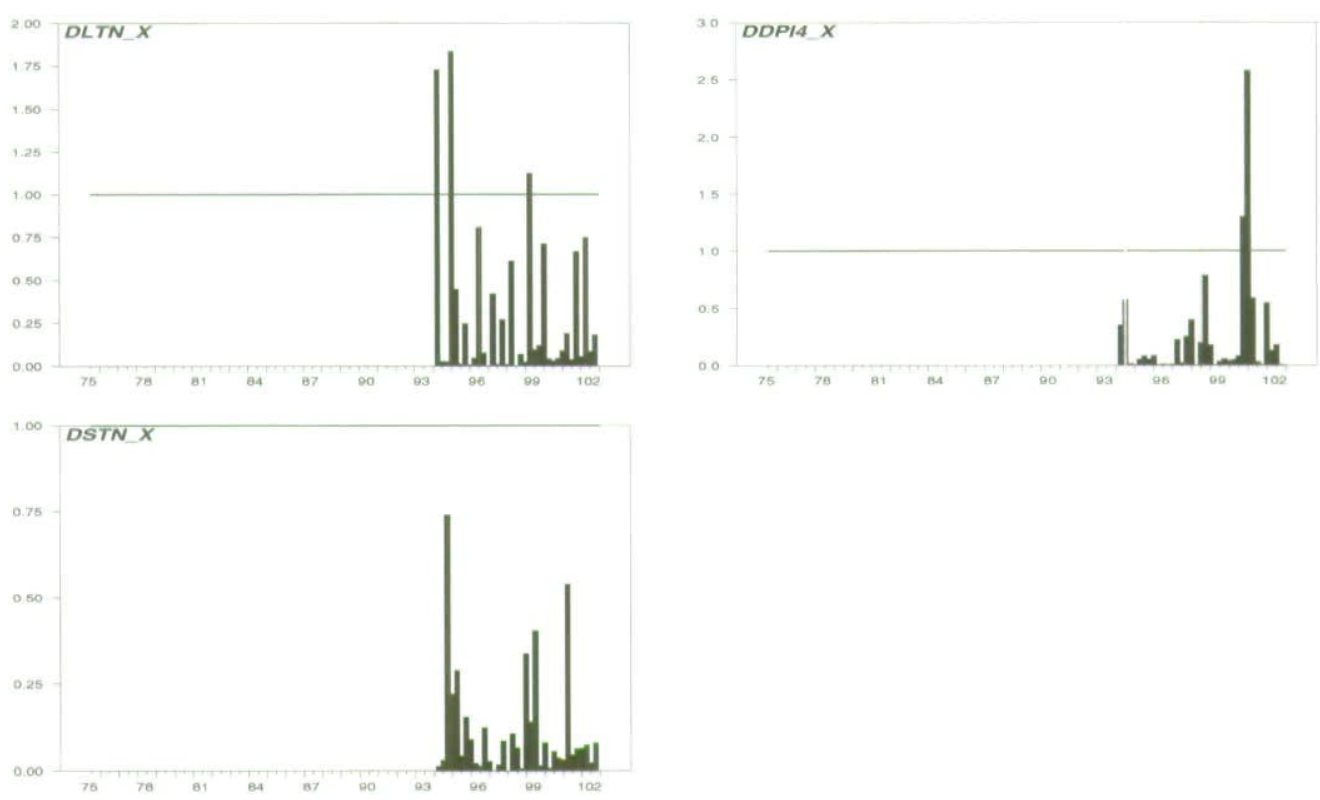

Figure 2. One-Step-Ahead Prediction Errors for the Individual Variables: Prediction Period 1996-2005

rate appreciation, lowering the value of import prices in domestic currency. Finally, inflation also adjusts to the relation linking the short-run interest rate and the interest rate spread. This confirms the predictive ability of the spread as an indicator of the economy from a cyclical perspective as well as the ability of the ECB to curb inflation.

European long-run interest rates are caused in the long-run only by the second cointegration relation, that is, the equilibrium relationship for the short-run real interest rates. No such causality is found in the other two cointegration relationships. The link between shortrun interest rate and long-run interest rate adjustment appears just when the foreign variables are accounted for. ${ }^{4}$ Thus, the euro/dollar real exchange rate appreciates when the ECB increases the short-run interest rate and is also equilibrium correcting to the second cointegration relationship.

Concerning the stability of the estimated model, Figure 1 reports the recursive Hansen and Johansen (1999) tests for the parameters in the cointegration space. From the tests for $\beta, \hat{\alpha}_{1}$, and $\hat{\alpha}_{2}$ constancy (see panels a, b, and c, respectively), the conclusion is that the cointegration space is clearly stable. Finally, Figure 2 shows the one-step-ahead prediction er or for each of the variables of the system. A test value above one implies that the model is not able to predict that observation within the $95 \%$ confidence interval. The predictive ability of the model turns out to be generally very good, especially in the case of the short-run interest rate. The exceptions are, in the case of long-run interest rates, the large shocks of 1994 and 1995 and the beginning of 2001 for the inflation rate.

\footnotetext{
${ }^{4}$ Even if relatively weak (the corresponding $t$-statistic is 1.74 for the loading to the cointegration relationship), it is remarkable that this is the only channel of adjustment for long-run interest rates.
} 


\section{Conclusions}

In this article, we have analyzed, using a VAR system approach based on the Johansen methodology, the relationship linking both long- and short-term interest rates and inflation for Euro-wide aggregate variables as well as short-term interest rates and inflation for the United States. According to our results, monetary policy shocks, generated by an estimated interest rate rule, influence short-run interest rates, real exchange rates, and inflation. However, in addition to monetary policy shocks, these variables are also influenced by autonomous market shocks caused by an increasing degree of financial integration. Long-run interest rates react to the short-run real interest rates.

The evidence in favor of the EH is found both in the long-run relationships and in the dynamics of the estimated model. First, there is a cointegration relation between long- and short-run interest rates in the third cointegration equation. Second, long-run interest rates show a dynamic adjustment to the second cointegration vector. It should be stressed that this dynamic adjustment behavior appears only once the external variables (foreign real interest and real exchange rate) are included in the cointegration vector. In this case, a dynamic relationship can be found between short- and long-term interest rates.

\section{References}

Bekaert, G., and R. J. Hodrick. 2001. Expectations hypotheses tests. Journal of Finance 56:1357-94.

Belke, A., and D. Gross. 2005. Asymmetries in the transatlantic monetary policy relationship: Does the ECB follow the Fed? Journal of Common Market Studies 43:921-46.

Brüggemann, R., and H. Lütkepohl. 2005. Uncovered interest rate parity and the expectations hypothesis of the term structure: Empirical results for the US and Europe. Applied Economics Quarterly 51:143-54.

Camarero, M., and C. Tamarit. 1996. Cointegration and the PPP and the UIP hypotheses: An application to the Spanish integration in the EC. Open Economies Review 7:61-76.

Campbell, J. Y., and R. J. Shiller. 1987. Cointegration and tests of present value models. Journal of Political Economy 95:1062-88.

Carriero, A., C. A. Favero, and I. Kaminska. 2006. Financial factors, macroeconomic information and the expectations theory of the term structure of interest rates. Journal of Econometrics 131:339-58.

Fagan, G., J. Henry, and R. Mestre. 2005. An area-wide model (AWM) for the Euro area. Economic Modelling 22:39-59.

Hansen, H., and S. Johansen. 1999. Some test for parameter constancy in cointegrated VAR-models. Econometrics Journal 2:306-33.

Johansen, S., and K. Juselius. 1992. Testing structural hypothesis in a multivariate cointegration analysis of the PPP and the UIP for UK. Journal of Econometrics 53:211-44.

Juselius, K. 1995. Do purchasing power parity and uncovered interest rate parity hold in the long-run? An example of likelihood inference in a multivariate time-series model. Journal of Econometrics 69:211-40.

Juselius, K., and R. MacDonald. 2004. International parity relationships between the USA and Japan. Japan and the World Economy 16:17-34.

Kluger, P. 2000. The expectations hypothesis of the term structure of interest rates, open interest rate parity and central bank policy reaction. Economic Letters 66:209-14.

Lucas, R. E. 1976. Econometric policy evaluation: A critique. Carnegie-Rochester Conference Series on Public Policy 1:19-46.

McCallum, B. T. 2005. Monetary policy and the term structure of interest rates. Economic Quarterly, Federal Reserve of Richmond, (Fall):1-21.

Neely, C. J. 2001. International interest rate linkages. International Economic Trends, Federal Reserve Bank of St. Louis. (August):1. 
Copyright of Southern Economic Journal is the property of Southern Economic Association and its content may not be copied or emailed to multiple sites or posted to a listserv without the copyright holder's express written permission. However, users may print, download, or email articles for individual use. 